\title{
CHROMOSOMAL TRANSLOCATION IN A MONGOLOID MALE CHILD AND HIS NORMAL MOTHER
}

\author{
WILLY BEÇAK * \\ JoYCE D. ANDRADE *
}

\author{
Maria Luiza BeÇaK * \\ ANTRANIK MANISSADJIAN **
}

The presence of 47 chromosomes in mongoloids, due to the trisomy of a small acrocentric chromosome in the 21-22 group (Denver system) was demonstrated by Lejeune et al.11 in 1959, and since that time has been confirmed by numerous authors (Beçak ${ }^{2}$ ). The production of this trisomy is explained by a defect in the process by which the homologous chromosomes or sister chromatids should dislocate from the opposing poles during the gametogenesis. Non disjunction which. results in the trisomy of 21 chromosome generally occurs in individuals with normal karyotypes and is influenced by etiological factors associated with maternal age.

The bi-modal distribution of mongolism according to maternal age shows, in certain cases, the influence of other factors. On the other hand, the frequency with which, in certain families, there occurs more than one mongoloid, is higher than expected by coincidence of independent occureences. Also in these cases the maternal age is not a preponderant etiological factor (Penrose et al.12).

Investigating cases of mongoloids born of young mothers, Polani et al. ${ }^{13}$ found in one child that the karyotype was abnormal, in spite of the fact that the child had the normal 46 chromosomes. Instead of one of the large acrocentrics of 13-15 group they found a larger chromosome which seemed to be due to the translocation between the absent chromosome with a 21 chromosome. The child, therefore, would be virtually trisomic for the 21 chromosome as in other mongoloids.

Carter et al. ${ }^{6}$ verified that in the family of a mongoloid with 46 chromosomes, the mother, aunt, and maternal grandmother, in spite of apparent normality, possessed only 45 chromosomes, presenting a translocation between a number 21 chromosome and a chromosome of 13-15 group. The simple translocation apparently did not result in phenotypical alterations in these generations, but made possible the formation of gametes with a $13-15 / 21$ besides the normal 21. The union of a gamete of this type with a normal one, which carries a 21 chromosome, originates in a zygote with 46 chromosomes, but with the genetic material of 21 in triplicate.

* From th Genetic Section of Instituto Butantan,

* Department of Pediatrics, Hospital das Clínicas, Faculdade de Medicina da Universidade de São Paulo (Prof. Pedro de Alcântara). 
Penrose et al. ${ }^{12}$ studied another family in which the grandmother, mother and daughter were found to have 45 chromosomes. The latter had given birth to two mongoloid children with 46 chromosomes, verifying in these karyotypes the existence of translocation 13-15/21.

Fraccaro et al. 9 reported a case of a mongoloid male child with 46 chromosomes, but who had only three autosomes in the 21-22 group, verifying the presence in these cells of an extra metacentric which was interpreted as an additional 19 or 20 , or resulting from a reciprocal translocation between two 21 chromosomes. The interpretation was complicated by the presence, in the skin cells of the father of the patient, phenotypically normal, of what appeared to be an extra 19-chromosome.

Forssman and Lehman ${ }^{8}$ observed, in two phenotypically normal males, the existence of a translocation $15 / 21$ in one case and $21 / 22$ in the other; both were parents of mongoloids, bearers of translocations.

Ek et al. ${ }^{7}$ described the case of a mongoloid male child who had two sisters and a maternal aunt who were mongoloids. The patient showed 46 chromosomes with apparent reciprocal translocations 15/21.

Breg et al.5, studying 12 mongoloid patients born of young mothers, observed trisomy of 21 in 10 cases and translocation 13-15/21 in 2 cases. The normal mother and brother of one of the mongoloids with 46 chromosomes were carriers of translocation and showed 45 chromosomes.

Biesele et al. ${ }^{4}$ also related the case of a mongoloid with 46 chromosomes. The mother of the child, who was apparently normal, had only 45 chromosomes and presented a translocation 15/21.

In this paper we will describe the case of a male mongoloid child (Down's syndrome) with a translocation 21/13-15. The mother, who was phenotypically normal, had 45 chromosomes and the same translocation $21 / 13-15$, which was transmitted to her mongoloid child.

\section{CASE REPORT}

A. Z., Jr., white, male, was born February 13, 1962, of young, unrelated and apparently normal parents (mother 24 years of age, father 30 ). This was the mother's first pregnancy, and the delivery was normal after 7 hours of labor. The child was slow to cry and breathe, but started soon after oropharyngeal cleasing. Birth weight was $2,600 \mathrm{~g}$, length $50 \mathrm{~cm}$. There was no aparent jaundice in the neo-natal period.

The infant was examined on May 18, 1962, at three months of age, and showed retardation of neuro-psychomotor development (when placed in a prone position he tried but was unable to raise his head). His weight at the time of this examination was $5,100 \mathrm{~g}$, length $59 \mathrm{~cm}$, cranial perimeter $39 \mathrm{~cm}$, and thoracic perimeter $37 \mathrm{~cm}$. The child showed hyporeactivity during the entire examination and the skin was pale and dry. The facial expression was hypomimical, although uncharacteristic. A neurological examination revealed a slight generalized hypotonia.

The present case was reviewed when the child was 7 months of age because of an accentuation of hyporeactivity and retardation in his neuropsychomotor development. He still had generalized hypotonia although not extremely intense, and 
a diminished hypomimical facial expression. In a radiological examination the dorsolumbar column as well as the hands and wrists exhibited normal bone texture. The presence of three nuclei of ossification in the wrist was noted along with the absence of the distal epiphysis of radius. The radiologically evaluated bone age corresponded with the chronological evaluation.

In view of these results a chromosomal study was made to verify the diagnostic hypothesis of mongolism. A cytogenetic study of the patient and his parents was made with respect to the leucocytes of peripheral blood. This was done according to the Beçak technigue .

The patient's count revealed a somatic number of 46 chromosomes. In a total of 20 somatic metaphases, 16 showed 46 chromosomes, two 47, and two less than 46 chromosomes. The cells of 46 chromosomes when paired (Denver system), revealed the presence of only 5 acrocentrics in the 13-15 group instead of 6 found in normal karyotypes, and 5 acrocentrics in the 21-22-Y instead of 6 usually found
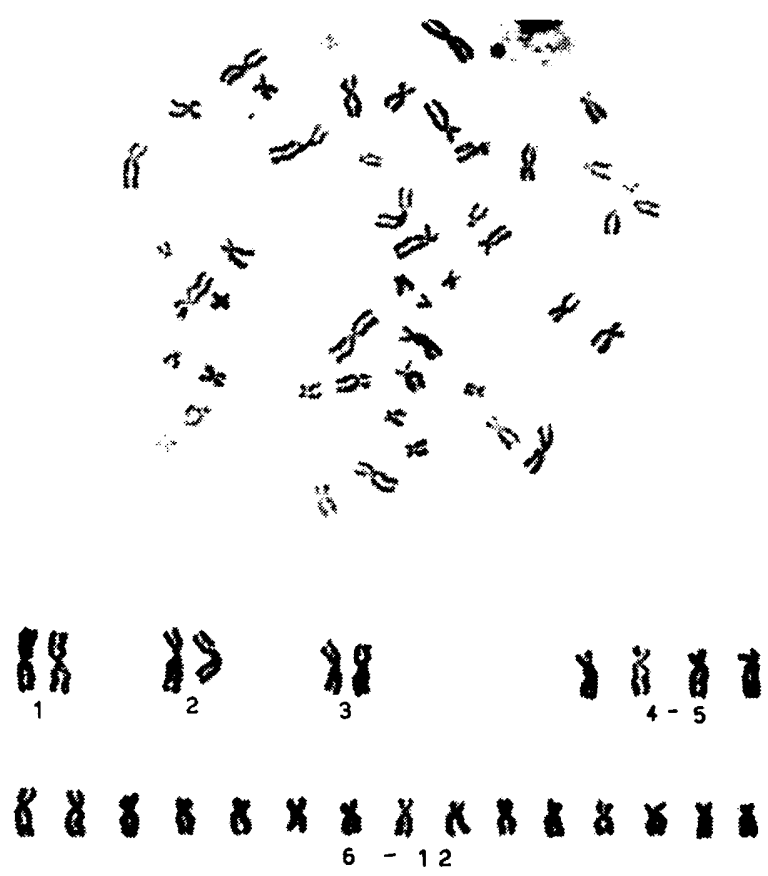

A $\$$.

$13-15$

$x \times x \times$ an

$\begin{array}{lll}16 & 17 & 18\end{array}$

$$
\underset{19-20}{*}+\frac{1}{21-22}
$$

Fig. 1 - Above, somatic metaphases of cultivated leucocytes of the mongoloid boy (46 chromosomes); below, karyotype of the same cell showing translocated chromosome 21/13-15. 

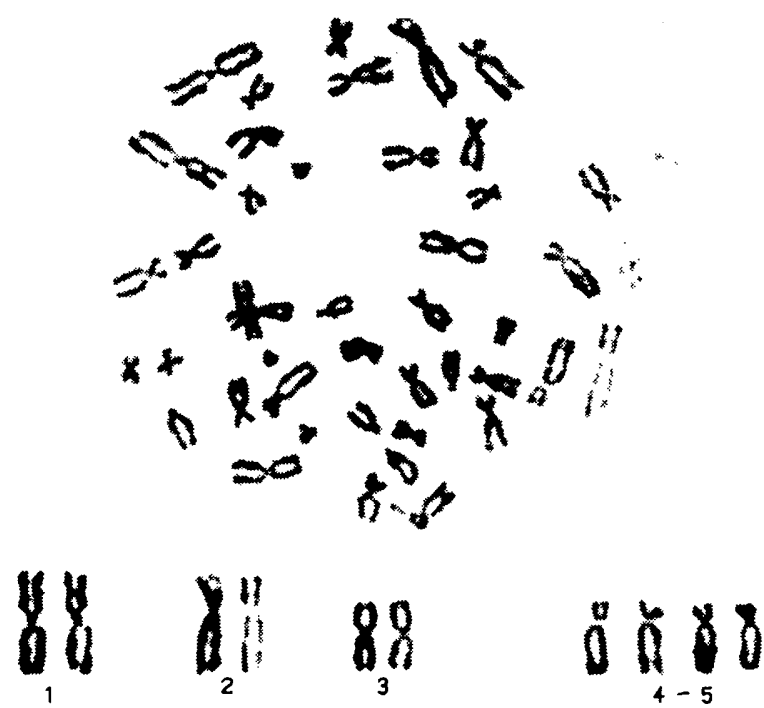

\section{$18861888 \times 858088$ $6-12$}
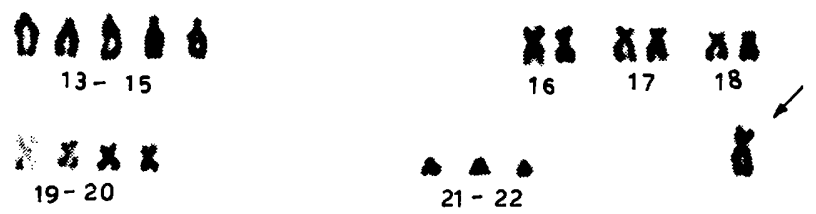

Fig. 2 - Above, a cell from the mother of the patient (45 chromosomes); below, karyotype of the cell showing translocated chromosome 21/13-15.

in male mongoloids. In group 6-12-X there appeared 16 chromosomes instead of the 15, normally found in the male karyotype. The cells of the 47 chromosomes of this culture, like those of the 46 chromosomes, demonstrated 5 acrocentrics in the 13-15 group and an extra submetacentric in the 6-12-X group. Besides this, they also exhibited an additional small acrocentric which would be classified in the 21-22-Y group.

The mother's count indicated a somatic number of 45 chromosomes. In the 23 methaphases studied, 21 showed 45 chromosomes, one 46 and one 44 . The cells with 45 chromosomes, when paired, apparently contained only 5 chromosomes in the 13-15 group instead of 6 found in normal individuals. The 21-22 group lacked an autosome - only 3 chromosomes in this group appeared in the karyotype instead of 4 found in the normal female. On the other hand, in the 6-12-X group 17 chromosomes were classified instead of 16 which are characteristic of the female karyotype.

The father's count indicated a somatic number of 46 chromosomes. The cells with 46 chromosomes, when paired, presented a normal karyotype with sexual chromosomes XY. 


\begin{tabular}{|l|c|c|c|c|c|}
\cline { 2 - 5 } & \multicolumn{3}{|c|}{ Number of chromosomes } & Cell total \\
\cline { 2 - 5 } & 44 & 45 & 46 & 47 & 20 \\
\hline Patient & 1 & 1 & 16 & 2 & 23 \\
\hline Mother & 1 & 21 & 1 & - & 16 \\
\hline
\end{tabular}

Table 1 - Chromosomal count in cultivated leucocytes of peripheral blood of the mongoloid patient and his parents.

\section{DISCUSSION}

The absence, in the mother, of one chromosome of the 13-15 group and one of the 21-22 group and the absence in the mongoloid patient of one autosome of the 13-15 group, and the presence in both mother and child of the extra submetacentric lead to the conclusion that this chromosome arose by translocation of a small acrocentric 21-22 to a large acrocentric 13-15. The maternal meiotic non-disjunction would produce a gamete with 23 chromosomes containing a normal 21 chromosom and a 21 translocated. The fertilization of this ovule by a normal spermatozoid containing a 21 chromosome, resulted in the chromosomal constitution of a mongoloid child which possessed a pair of 21 autosomes and a translocation 21/13-15 of maternal origin and therefore a karyotype with 46 chromosomes which in reality is trisomic for the 21 .

The fact that the patient does not possess all the characteristics of mongolism could be explained by "incomplete trisomy", that is, comprising all of the 21 chromosome, a segment of which could be lost during translocation. The "incomplete trisomy" would be implied in the deficiency of this same segment in the maternal cells. Notwithstanding, the mother of the patient is apparently normal.

In this patient two analyzed cells of 47 chromosomes were apparently tetrasomic for the 21 chromosomes. Besides a translocation 21/13-15 also encountered in other cells, there is still a small extra acrocentric, considered as a 21 chromosome. These cells might have originated by a meiotic "nondisjunction" which, added to meiotic non-disjunction of the same chromosome, might have resulted in tetrasomy of the 21 . It is possible that the lack of equilibrium in this chromosomic pair facilitated the occurrence of new aberrations in the same chromosomic pair, which might explain the successive alterations observed in relation to the 21 autosome.

A young maternal second cousin of the patient also has a female child with neuro-psychomotor retardation. Unfortunately, it was impossible to examine their karyotypical constitution. It is possible that this case too is mongoloid, permitting the supposition of the abnormal origin in a common ancestor, i.e., one of the maternal grandmothers of those affected. In such a circumstance, by the genealogy, one of the carriers of translocation would be the maternal grandfather of the patient. 
It is interesting to note that in all the analyzed cells of the patient and his father, the $\mathrm{Y}$ chromosome appeared significantly larger in relation to others of the 21-22 group, a phenomenon previously observed by others (Bender et al. ${ }^{3}$, Hungerford ${ }^{10}$ ). It should be noted that in the analyzed cells of the individuals in one study, the $\mathrm{Y}$ chromosome was larger than the chromosomes of the 19-20 group, corresponding in size to those of pair 18. In some cells the $\mathrm{Y}$ chromosome reached the size of pair 17 and even of pair 16.

\section{SUMMARY}

The presence of a translocation $21 / 13-15$ is related in 46 chromosomes, karyotypes of a mongoloid male child (Down's syndrome). The abnormal chromosome was transmitted by the mother of the patient. The possible deficiency of translccated chromosome 21 and the possible origin of the anomaly in the family was discussed and the presence of a markedly large $\mathrm{Y}$ chromosome in the karyotypes of the patient as in those of his father was also noted.

\section{RESUMO}

É relatada a presença de uma translocação 21-13/15 nos cariótipos com 46 cromossomos de um menino mongolóide (síndrome de Down), sendo o cromossomo anômalo transmitido pela mãe do paciente. São discutidas a possivel deficiência do cromossomo 21 translocado, e a possivel origem da anomalia na família. É assinalada a presença de um cromossomo $\mathrm{Y}$ marcadamente grande, tanto nos cariótipos do paciente como nos do seu pai.

\section{REFERENCES}

1. BECAK, W. - Human chromosomes in short term cultures from peripheral blood leucocytes. Rev. Bras. Biol., 21:281-286, 1961. 2. BECAK, W. - Desenvolvimento e aplicações da citogenética humana na patologia. Rev. Bras. Cirurg., 44: 298-310, 1962. 3. BENDER, M. A. and GOOCH, P. C. - An unusually long human Y chromosome. Lancet 2:463-464, 1961. 4. BIESELE, J. J.; SCHMID, W; .LEE, C. H. and SMITH, P. M. - Translocation between acrocentric chromosomes in a 46 chromosome mongoloid and his 45 chromosome mother. Ann. J. Human. Gen., 14: 125-134, 1962. 5. BREG, W. R.; MILLER, O. J.; SCHMICKEL, R. D. - Chromosomal translocations in patients with mongolism and in their normal relatives. New Engl. J. Med., 266:845-852, 1962. 6. CARTER, C. O.; HAMERTON, J. L.; POLANI, P. C.; GUNALP, A.; WELLER, S. D. U. - Chromosome translocation as a cause of familial mongolism. Lancet 2:678-690, 1960. 7. EK. J. D.; FALK, V.; BERGMAN, S.; REITALU, J. - A male mongoloid with 46 chromosomes. Lancet 2:526-527, 1961.8. FORSSMAN, H.; LEHMANN, O. - Translocation carrying phenotypically normal males and the Down syndrome. Lancet 1:1286, 1961. 9. FRACCARO, M.; KAIJSER, K.; LINDSTEN, J. - Chromosomal anormalities in father and mongol child. Lancet 1:724-727, 1960. 10. HUNGERFORD, D. A. - Observations on the morphology and behavior of normal chromosomes (in press). 11. LEJEUNE, J.; GAUTIER, M.; TURPIN, R. - Les chromosomes humaines en culture de tissues. Compt. rend. Acad. Sc. (Paris) 248:602-603, 1959. 12. PENROSE, L. S.; ELLIS, J. R.; DELHANIY, J. D. - Chromosomal translocation in mongolism and in normal relatives. Lancet 2:409-410, 1960. 13. POLANI, P. E.; BRIGGS, J. H.; FORD, C. E.; CLARKE, C. M. - A mongol girl with 46 chromosomes. Lancet 1:721-724, 1960. 